\title{
STUDIES ON INHIBITORS OF RAT MAST CELL DEGRANULATION PRODUCED BY MICROORGANISMS \\ I. SCREENING OF MICROORGANISMS, AND ISOLATION AND PHYSICO-CHEMICAL PROPERTIES OF EUROCIDINS C, D AND E
}

\author{
Kazuya Nakagomi, Makoto Takeuchi ${ }^{\dagger}$, Hideoki Tanaka \\ and NoBORU TOMIZUKA ${ }^{\dagger \dagger}$ \\ Fermentation Research Institute, Agency of Industrial Science and Technology, \\ Tsukuba, Ibaraki 305, Japan
}

TERUMI NAKAJIMA

Faculty of Pharmaceutical Sciences, University of Tokyo, Hongo, Bunkyo-ku, Tokyo 113, Japan

(Received for publication December 5, 1989)

\begin{abstract}
Microorganisms producing anti-inflammatory substances were screened by the inhibitory effect on mast cell degranulation. Three new compounds related to pentaene macrolide eurocidins, eurocidins C, D and E, have been isolated from the culture broth of Streptoverticillium eurocidicum IFO 13491 as the inhibitors. Their molecular weights and molecular formulae were estimated as 781.89 and $\mathrm{C}_{39} \mathrm{H}_{59} \mathrm{NO}_{15}$ for eurocidin $\mathrm{C}, 795.92$ and $\mathrm{C}_{40} \mathrm{H}_{61} \mathrm{NO}_{15}$ for eurocidin $\mathrm{D}$, and 779.92 and $\mathrm{C}_{40} \mathrm{H}_{61} \mathrm{NO}_{14}$ for eurocidin $\mathrm{E}$, respectively.
\end{abstract}

By inflammatory stimulations such as heat shock, cold shock, toxins, medicines and antigen-antibody complexes, cytoplasmic granules and various chemical mediators including histamine, serotonin and prostaglandins are released from mast cells, and these materials are known to cause various allergic and inflammatory reactions ${ }^{1)}$. Mast cells have been recognized as one of the mediator cells of inflammatory and allergic reactions in animals ${ }^{2}$.

YAMASAKI $e t ~ a l .{ }^{3)}$ reported that the inhibitory activities of drugs against mast cell degranulation in vitro show a good correlation with their anti-inflammatory effects in vivo, and HrRAI et al. ${ }^{4}$ reported the screening of anti-inflammatory chinese drugs based on inhibitory effect of histamine release from mast cells. We have developed a simple and fast screening method for microorganisms (culture filtrates and mycelium extracts) by the inhibitory effects on mast cell degranulation induced by compound $48 / 80^{5}$ ) a typical inducer of rat peritoneal mast cell degranulation ${ }^{6}$. New anti-allergic and anti-inflammatory substances of microbial origin are expected to find out by this screening method.

In this paper, we report the screening of microorganisms producing anti-inflammatory materials, isolation and physico-chemical properties of new compounds of eurocidin family inhibiting rat mast cell degranulation.

\section{Materials and Methods}

Chemicals

Chemicals employed were as follows: Bovine serum albumin (BSA) and compound 48/80 from Sigma

Present address: ${ }^{\dagger}$ The Nikka Whisky Distilling Co., Minami-Aoyama, Minato-ku, Tokyo 107, Japan. ${ }^{\dagger \dagger}$ Industrial Technology Center of Okayama Prefecture, Okayama 700, Japan. 
Chemical Co., St. Louis, U.S.A.; CM-Toyopearl 650M and DEAE-Toyopearl 650M from Tosoh Co., Ltd., Tokyo, Japan; MCI gel CHP20P from Mitsubishi Chemical Industries Limited, Tokyo, Japan; packed column of Lichrosorb RP-8 ( $5 \mu \mathrm{m}, 125 \times 4 \mathrm{~mm}$ i.d.) and Lobar column (Lichroprep RP-18, size B) from E. Merck, Darmstadt, FRG; Nucleosil $5 \mathrm{C}_{8}$ column $\left(250 \times 10 \mathrm{~mm}\right.$ i.d.) and Nucleosil $5 \mathrm{C}_{8}$ column $(250 \times 20 \mathrm{~mm}$ i.d.) for preparative HPLC from Chemco Co., Osaka, Japan; YMC A-302 column ( $5 \mu \mathrm{m}$, $150 \times 4.6 \mathrm{~mm}$ i.d.) from Yamamura Chemical Laboratories Co., Kyoto, Japan; and TMS-250 column $(75 \times 4.6 \mathrm{~mm}$ i.d.) from Tosoh Co., Ltd., Japan. All other chemicals were of analytical grade. Reference substance was a gift from Takeda Chemical Industries Ltd., Japan, designated as Eurocidin- $T$ in this paper.

\section{Physico-chemical Studies}

The UV spectra were recorded on a Hitachi 220A or a Shimadzu UV250 spectrophotometer in $\mathrm{MeOH}$ solutions, and IR spectra on a Jasco A302 IR spectrophotometer with $\mathrm{KBr}$ method. Mass spectra were obtained with a Jeol JMS HX100 mass spectrometer.

\section{Cultivation of Microorganisms}

Actinomycetes from type cultures and microorganisms isolated from soil samples were cultured at $28 \sim 30^{\circ} \mathrm{C}$ in test tubes for $3 \sim 4$ days with the culture medium containing glucose $1.5 \%$, Polypeptone $0.5 \%$, meat extract $0.5 \%$, yeast extract $0.5 \%$ and $\mathrm{NaCl} 0.5 \%$, and the $\mathrm{pH}$ was adjusted to 7.0 .

Cultivations for the production of active substances were carried out in the same medium. The spores of Streptoverticillium eurocidicum IFO 13491 were inoculated into $40 \mathrm{ml}$ of a medium in a $200-\mathrm{ml}$ Sakaguchi flask and cultured at $28^{\circ} \mathrm{C}$ for 3 days on a reciprocal shaker. Twenty $\mathrm{ml}$ of the above seed culture was transferred to $1,200 \mathrm{ml}$ of the same medium in a 5 -liter Erlenmeyer flask and cultured at $28^{\circ} \mathrm{C}$ for approximately 40 hours.

\section{Preparation of Rat Peritoneal Mast Cells}

Mast cells were collected from peritoneal cavities of normal Wistar rats weighing $150 \sim 250 \mathrm{~g}$ as described by HIRaI et al. ${ }^{4}$. The cells were suspended in TYrODE's solution $(\mathrm{NaCl} 137 \mathrm{mM}, \mathrm{KCl} 2.7 \mathrm{~mm}$, $\mathrm{MgCl}_{2} 1.0 \mathrm{~mm}, \mathrm{CaCl}_{2} 1.8 \mathrm{~mm}, \mathrm{NaH}_{2} \mathrm{PO}_{4} 0.4 \mathrm{~mm}, \mathrm{NaHCO}_{3} 11.9 \mathrm{~mm}$ and glucose $5.6 \mathrm{~mm}$ ) and layered on BSA-saline solution whose density and $\mathrm{pH}$ were adjusted to 1.068 and 7.0 , respectively. After centrifugation at $100 \times \mathrm{g}$ at $4^{\circ} \mathrm{C}$ for 12 minutes, the bottom layer containing mast cells was washed twice with $5 \mathrm{ml}$ of $0.1 \%$ BSA in TYRODE's solution, and suspended in the same medium at about $10^{6} \mathrm{cells} / \mathrm{ml}$. The purity of mast cells was about $80 \sim 90 \%$ as observed with an Olympus phase contrast microscope.

Screening of Microorganisms

Culture filtrates were separated from microbial cells by centrifugation or filtration, added to 10 volumes of phosphate buffered saline (PBS), and then applied to the screening. Microbial cells were extracted with $\mathrm{MeOH}$. The extracts were evaporated to dryness in vacuo and the residues were dissolved in PBS to be applied to the screening.

The assay method about screening of microorganisms for the inhibitory effect on mast cell degranulation was as follows; compound 48/80 was used as an inducer of mast cell degranulation. Twenty $\mu 1$ of cell suspension was added to $20 \mu \mathrm{l}$ of a test sample, and the mixture was incubated for 10 minutes, then another 5 minutes with compound $48 / 80$. The degree of mast cell degranulation was measured by counting the degranulated cells under an Olympus phase contrast microscope $(\times 400)$. In the case of the measurement of inhibitory effect on histamine release, those cells were cooled on ice, then centrifuged at $1,500 \times g$ for 5 minutes after the incubation. Thirty $\mu$ l of the supernatant was applied to HPLC as described by HIRAI et $a l^{4)}$. The primary screening was carried out at $25^{\circ} \mathrm{C}$ (room temperature) with $1 \mu \mathrm{g} / \mathrm{ml}$ of the inducer, and then the secondary screening for the strains picked up in the primary screening was carried out at $37^{\circ} \mathrm{C}$ with $2 \mu \mathrm{g} / \mathrm{ml}$ of the inducer.

\section{Results and Discussions}

\section{Screening}

The primary screening was carried out using the culture filtrates of 2,032 strains of microorganisms 
Table 1. Primary screening for culture filtrates of microorganisms.

\begin{tabular}{|c|c|c|c|c|c|c|}
\hline \multirow{2}{*}{ Microorganisms } & \multirow{2}{*}{$\begin{array}{c}\text { Numbers of } \\
\text { strains }\end{array}$} & \multicolumn{5}{|c|}{ Inhibitory effects for degranulation } \\
\hline & & +++ & ++ & + & \pm & - \\
\hline $\begin{array}{l}\text { Actinomycetes } \\
\text { (type cultures) }\end{array}$ & 384 & 16 & 36 & 31 & 76 & 225 \\
\hline $\begin{array}{l}\text { Actinomycetes } \\
\text { (from soil) }\end{array}$ & 638 & 7 & 15 & 29 & 79 & 508 \\
\hline $\begin{array}{l}\text { Bacteria } \\
\text { (from soil) }\end{array}$ & 978 & 0 & 2 & 4 & 15 & 957 \\
\hline $\begin{array}{l}\text { Fungi } \\
\text { (from soil) }\end{array}$ & 32 & 0 & 0 & 0 & 0 & 32 \\
\hline Total & $\begin{array}{l}2,032 \\
(100 \%)\end{array}$ & $\begin{array}{c}23 \\
(1 \%)\end{array}$ & $\begin{array}{c}53 \\
(3 \%)\end{array}$ & $\begin{array}{c}64 \\
(3 \%)\end{array}$ & $\begin{array}{l}170 \\
(8 \%)\end{array}$ & $\begin{array}{l}1,722 \\
(85 \%)\end{array}$ \\
\hline
\end{tabular}

from soil samples and our type culture collections (1,022 of actinomycetes, 978 of bacteria and 32 of fungi) as described above (Table 1). Among them, 134 strains of actinomycetes and 6 strains of bacteria showed inhibitory activity against mast cell degranulation. The inhibitory effects were found more frequently in actinomycetes than in bacteria or fungi. In the secondary screening, 8 strains (Streptoverticillium albireticuli IFO 12737, Streptomyces californicus IFO 12750, Actinomyces streptomycini IFO 12918, Streptomyces ornatus IFO 13069, Streptomyces capoamus IFO 13411, S. eurocidicum IFO 13491, Streptomyces sp. from soil and Bacillus sp. from soil) among the above 140 strains were selected. Finally we decided $S$. eurocidicum IFO 13491 as the most suitable strain for stable production of potent active substances in repetitive cultivation.

\section{Isolation of Active Substances}

The inhibitory activity was observed both in the culture filtrate and mycelial cake of $S$. eurocidicum IFO 13491. The active principles were isolated according to the procedures outlined in Fig. 1.

Five liters of the culture broth was centrifuged to give a supernatant fluid and a mycelial cake (about $200 \mathrm{~g}$ at wet weight). The active substances in the supernatant were adsorbed to $500 \mathrm{ml}$ of Amberlite $\mathrm{XAD}-7$, and then eluted with 1.5 liters of $80 \% \mathrm{MeOH}$ after the resin was washed with water and with $20 \% \mathrm{MeOH}$. After the eluate was evaporated to dryness, the residue was dissolved in 1 liter of water, adjusted to $\mathrm{pH} 4.0$ and applied to a CM-Toyopearl $650 \mathrm{M}$ cation exchange column $(272 \times 50 \mathrm{~mm}$ i.d.) which was pre-equilibrated with $50 \mathrm{mM} \mathrm{AcONH}_{4}$ buffer ( $\mathrm{pH} 4.0$ ) before use. The column was washed with $50 \mathrm{~mm} \mathrm{AcONH}_{4}$ buffer ( $\mathrm{pH} 4.0$ ) and eluted with the same buffer ( $\left.\mathrm{pH} 6.0\right)$. Three active fractions (F-1, F-2 and F-3) were eluted at pH 4.8, 5.4 and 5.8, respectively (Fig. 2). Each fraction (F-1: $360 \mathrm{ml}, \mathrm{F}-2: 576 \mathrm{ml}$ and F-3: $648 \mathrm{ml}$ ) was adjusted to $\mathrm{pH} 9.0$ and applied to a DEAE-Toyopearl 650M anion exchange column $\left(230 \times 25 \mathrm{~mm}\right.$ i.d.) which was pre-equilibrated with $50 \mathrm{~mm} \mathrm{AcONH}_{4}$ buffer ( $\left.\mathrm{pH} 9.0\right)$ before use. The column was washed with $50 \mathrm{~mm} \mathrm{AcONH} 4$ buffer ( $\mathrm{pH} 9.0$ ) and eluted with the same buffer (pH 7.5). The active fractions were applied to a MCI gel CHP2OP column $(100 \times 12.5 \mathrm{~mm}$ i.d.) and the column was washed with water and with $20 \%$ acetonitrile, and then eluted with $40 \%$ acetonitrile solution. The eluates were concentrated and applied to preparative HPLC using a Nucleosil $5 \mathrm{C}_{8}$ column $(250 \times 20 \mathrm{~mm}$ i.d.) with acetonitrile - $10 \mathrm{~mm} \mathrm{AcONH}_{4}$ buffer (pH 5.0) (35:65) as a mobile phase. F-1, F-2 and F-3 were obtained 1,7 and $13 \mathrm{mg}$, respectively, as pale yellow powders.

The mycelial cake (200 g at wet weight) was extracted with 4 liters of $\mathrm{MeOH}$ at the room temperature 
Fig. 1. Isolation procedures for eurocidins $\mathrm{C}, \mathrm{D}$ and $\mathrm{E}$.

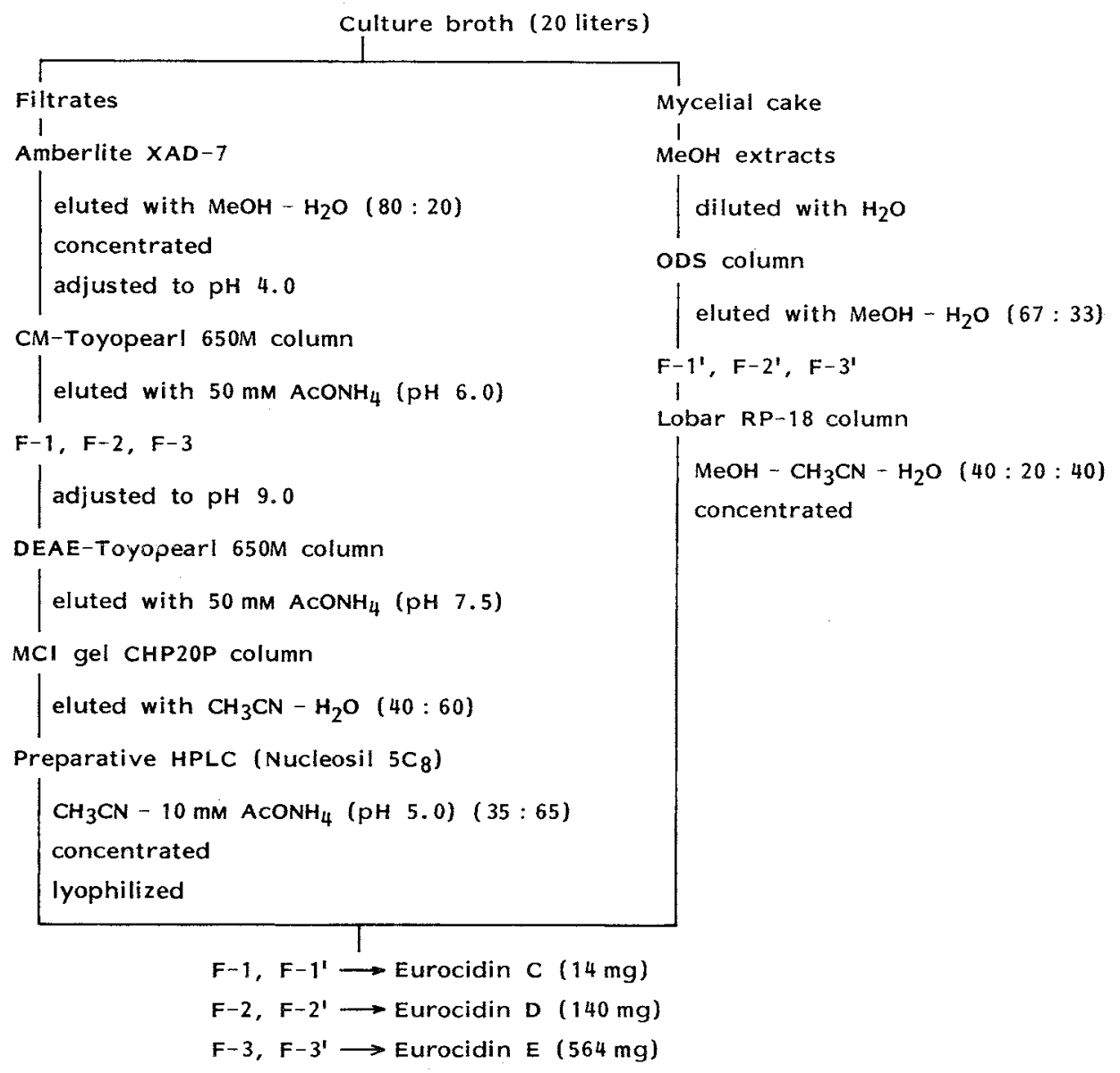

Fig. 2. CM-Toyopearl cation exchange column chromatogram for inhibitors in the culture filtrate.

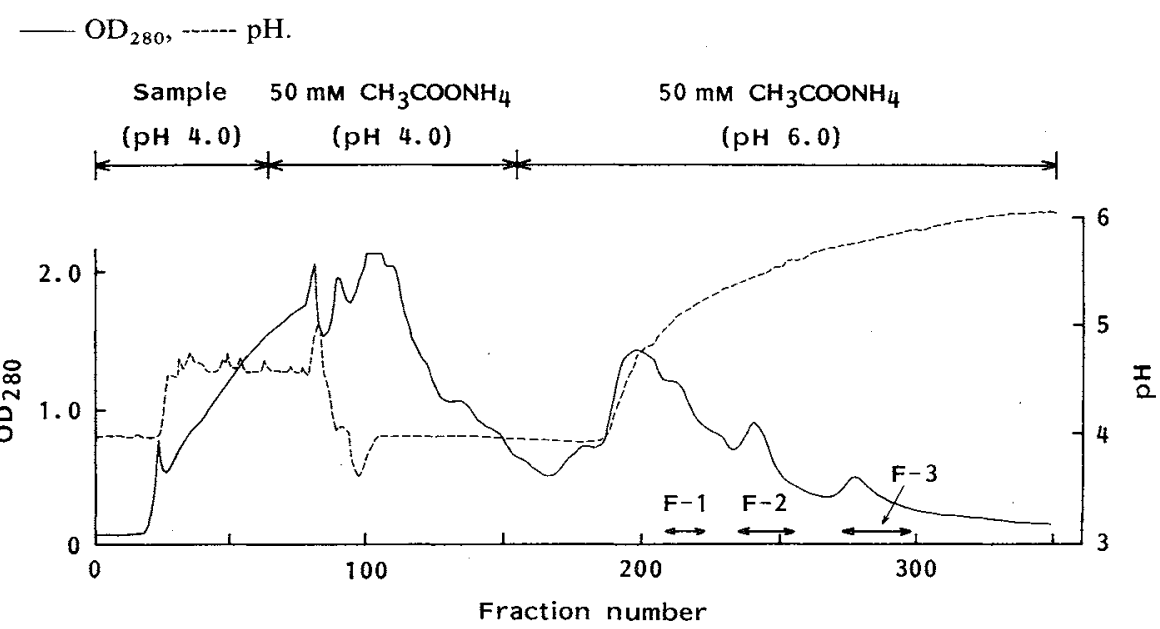

Column: CM-Toyopearl $650 \mathrm{M}(272 \times 50 \mathrm{~mm}$ i.d. $)$, sample: adjusted to $\mathrm{pH} 4.0$, eluent: $50 \mathrm{mM} \mathrm{AcONH}_{4}$ buffer (pH 6.0), flow rate: $96 \mathrm{ml} /$ hour, fraction: $24 \mathrm{ml} /$ tube. 
Fig. 3. ODS column chromatogram for inhibitors in the MeOH extracts of mycelial cake.

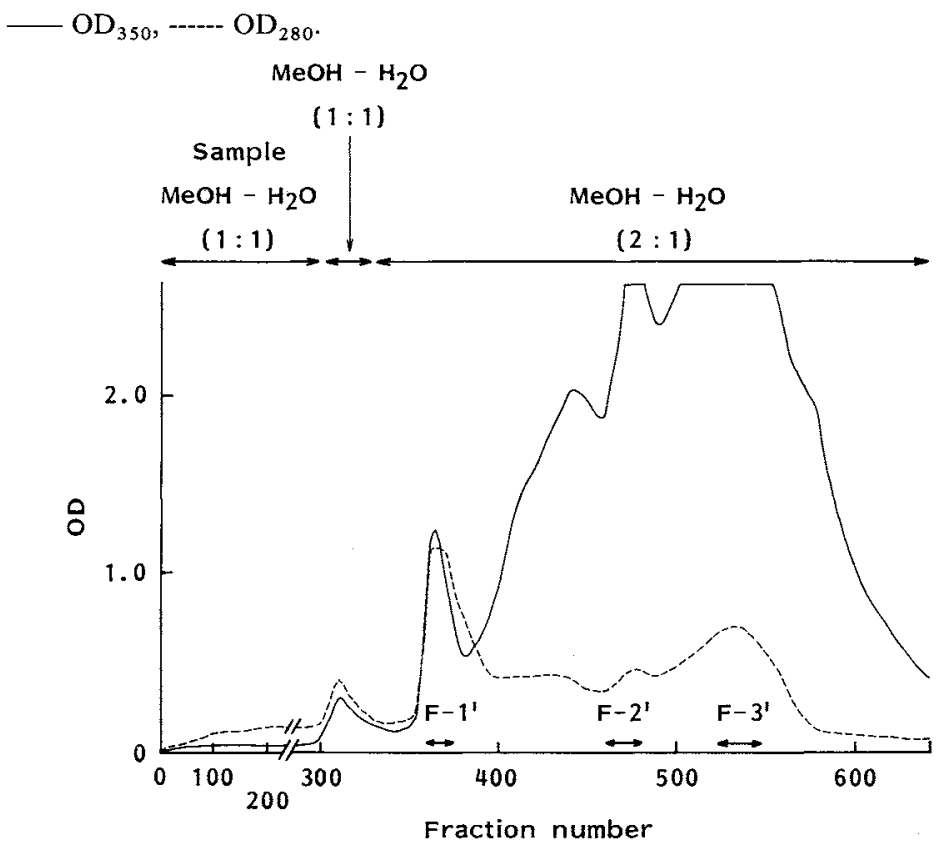

Column: ODS (75 150 $\mu \mathrm{m}, 275 \times 60 \mathrm{~mm}$ i.d.), sample: dissolved in $\mathrm{MeOH}-$ water (1: 1 ), eluent: MeOH - water (2:1), flow rate: $150 \mathrm{ml} /$ hour, fraction: $25 \mathrm{ml} /$ tube.

Table 2. Physico-chemical properties of eurocidins C, D and E.

\begin{tabular}{|c|c|c|c|}
\hline & $\begin{array}{l}\text { Eurocidin } C \\
\qquad(\mathrm{~F}-1)\end{array}$ & $\begin{array}{l}\text { Eurocidin D } \\
\qquad(\mathrm{F}-2)\end{array}$ & $\begin{array}{l}\text { Eurocidin } \mathrm{E} \\
\qquad(\mathrm{F}-3)\end{array}$ \\
\hline $\mathrm{MP}\left({ }^{\circ} \mathrm{C}, \mathrm{dec}\right)$ & $135 \sim 139$ & $135 \sim 139$ & $135 \sim 139$ \\
\hline \multicolumn{4}{|l|}{ Elemental analysis } \\
\hline Calcd $\left(+2 \mathrm{H}_{2} \mathrm{O}\right)$ & C $57.27, \mathrm{H} 7.76, \mathrm{~N} 1.71$ & C $57.75, \mathrm{H} 7.87, \mathrm{~N} 1.68$ & C $58.88, \mathrm{H} 8.03, \mathrm{~N} 1.72$ \\
\hline Found: & C 57.59, H 7.61, N 1.76 & C $57.70, \mathrm{H} 7.57, \mathrm{~N} 1.65$ & C $58.86, \mathrm{H} 8.10, \mathrm{~N} 1.86$ \\
\hline FAB-MS $(\mathrm{M}+\mathrm{H})^{+} m / z$ & 782 & 796 & 780 \\
\hline Calcd $(\mathrm{M}+\mathrm{H})^{+}$ & $(782.4)$ & $(796.5)$ & $(780.4)$ \\
\hline Molecular formula & $\mathrm{C}_{39} \mathrm{H}_{59} \mathrm{NO}_{15}$ & $\mathrm{C}_{40} \mathrm{H}_{61} \mathrm{NO}_{15}$ & $\mathrm{C}_{40} \mathrm{H}_{61} \mathrm{NO}_{14}$ \\
\hline MW & 781.89 & 795.92 & 779.92 \\
\hline IR $v_{\max }(\mathrm{KBr}) \mathrm{cm}^{-1}$ & $\begin{array}{l}3380,2940,1700,1560 \\
1390,1180,1070,1005\end{array}$ & $\begin{array}{l}3380,2940,1700,1560 \\
1380,1170,1070,1000\end{array}$ & $\begin{array}{l}3380,2940,1710,1560 \\
1380,1170,1070,1005\end{array}$ \\
\hline $\mathrm{UV} \lambda_{\max }^{\mathrm{MeOH}} \mathrm{nm}(\varepsilon)$ & $\begin{array}{l}302(32,600), 316(69,200) \\
331(113,000), 349(114,000)\end{array}$ & $\begin{array}{l}302(31,200), 316(66,500) \\
331(109,000), 349(111,000)\end{array}$ & $\begin{array}{l}302(31,400), 316(67,000), \\
331(110,000), 349(112,000)\end{array}$ \\
\hline
\end{tabular}

soaking overnight. The extract was diluted with an equal volume of water, and 8 liters of sample solution was applied to a preparative ODS column $(275 \times 60 \mathrm{~mm}$ i.d.) (Fig. 3). The column was eluted with $\mathrm{MeOH}$ - water $(2: 1)$ to provide three active fractions $\left(\mathrm{F}-1^{\prime}, \mathrm{F}-2^{\prime}\right.$ and $\left.\mathrm{F}-3^{\prime}\right)$, which were concentrated and purified by a Lobar column with the eluent of $\mathrm{MeOH}$-acetonitrile-water $(4: 2: 4)$. Each active fraction from F-1', F-2' and F-3' was evaporated to dryness in vacuo and was obtained $2.5,30$ and $128 \mathrm{mg}$, respectively, as pale yellow powders as well as those from the culture filtrate.

Active substances $\left(\mathrm{F}-1^{\prime}, \mathrm{F}-2^{\prime}\right.$ and $\left.\mathrm{F}-3^{\prime}\right)$ isolated from the mycelial cake were combined to $\mathrm{F}-1, \mathrm{~F}-2$ and F-3, respectively, because their physico-chemical data were identical with each other. F-1 (14 mg), F-2 (140 mg) and F-3 (564 mg) were obtained from 20 liters of a culture broth, as pale yellow powders. F-1, 
Fig. 4. IR spectra of eurocidins C (A), D (B) and E (C) (KBr tablet).
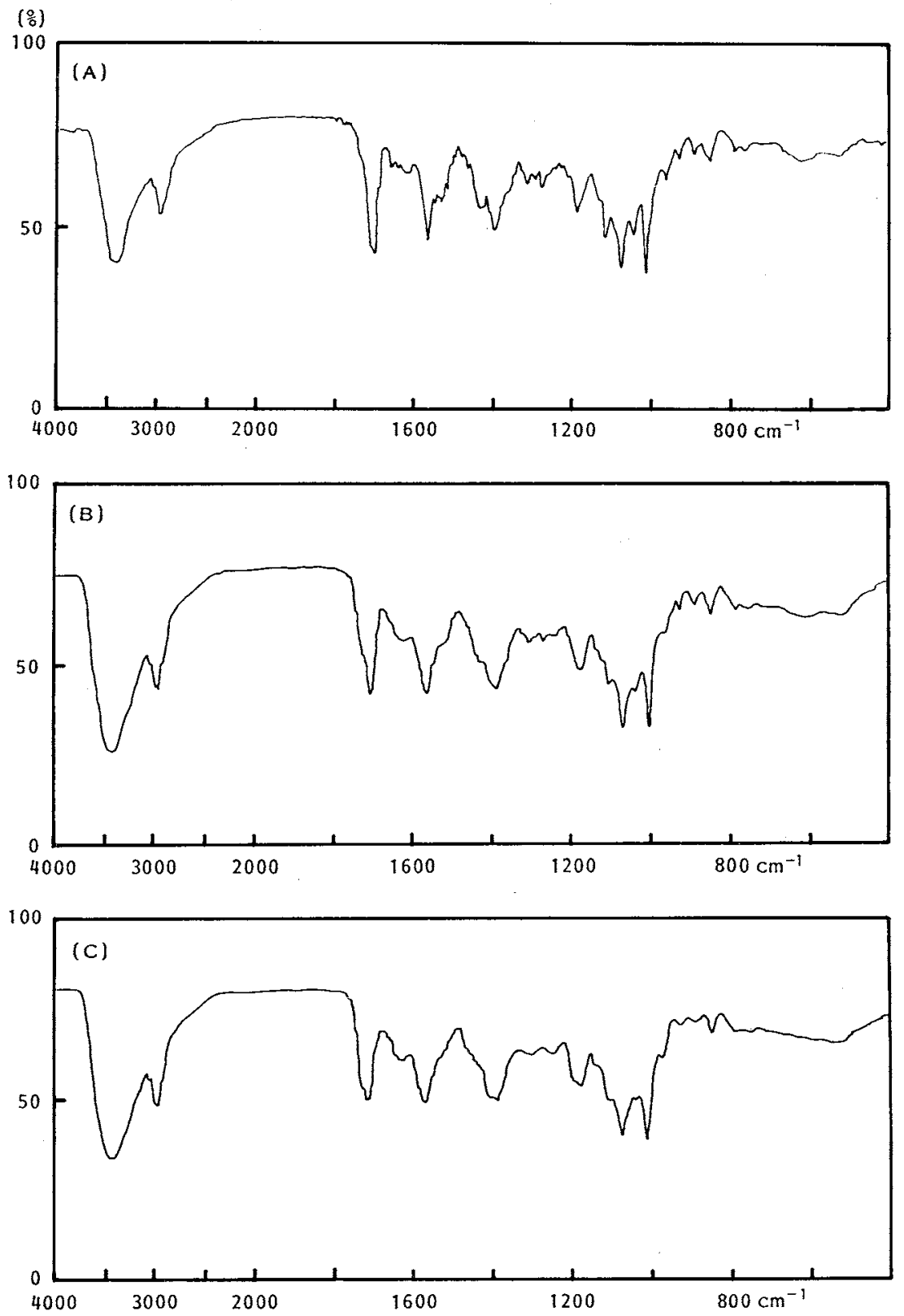

F-2 and F-3 showed an inhibitory effect on histamine release from rat mast cells induced by $1 \mu \mathrm{g} / \mathrm{ml}$ of compound $48 / 80$, and $\mathrm{IC}_{50}$ values were found to be about $5.0 \mu \mathrm{g} / \mathrm{ml}$ for F- $1,2.2 \mu \mathrm{g} / \mathrm{ml}$ for F-2 and $1.1 \mu \mathrm{g} / \mathrm{ml}$ for F-3, as well as inhibitory activity against mast cell degranulation.

Physico-chemical Properties

Physico-chemical properties of F-1, F-2 and F-3 are summarized in Table 2 and their IR spectra are shown in Fig. 4. From the mass spectral data and elemental analysis, the molecular weights and molecular formulae were estimated 781.89 and $\mathrm{C}_{39} \mathrm{H}_{59} \mathrm{NO}_{15}$ for F-1, 795.92 and $\mathrm{C}_{40} \mathrm{H}_{61} \mathrm{NO}_{15}$ for $\mathrm{F}-2$ and 779.92 
and $\mathrm{C}_{40} \mathrm{H}_{61} \mathrm{NO}_{14}$ for $\mathrm{F}-3$, respectively.

From the UV spectra, F-1, F-2 and F-3 were defined as the typical pentaene of polyene macrolide antibiotics. They were estimated as eurocidin-type compounds from producing microorganisms. Eurocidin was found by NAKAZAWA ${ }^{7)}$ as an anti-fungal antibiotic produced by $S$. albireticuli, and was designated as Eurocidin- $T$ in this paper. Eurocidin$T$ was a mixture of several related compounds. HORII et al. ${ }^{8)}$ reported the partial structure of Eurocidin$\mathrm{T}$ as a pentaene containing eurocidins $\mathrm{A}$ and $\mathrm{B}$, however the whole structure of any of eurocidins was still unknown.

Eurocidin-T showed two major peaks and some minor peaks when it was subjected to HPLC (Fig. 5B). F-1, F-2 and F-3 isolated in this experiment were detected as almost a single peak (Fig. $5 \mathrm{~A}$ shows the additive mixture of F-1, F-2 and $\mathrm{F}-3$ ). The retention time of $\mathrm{F}-1$ or F-2 was different from any component of Eurocidin- $T$, and only F-3 was eluted at similar retention time to that of one of the two major peaks of Eurocidin-T. The similar result was obtained by further HPLC analyses under different conditions using several different columns and mobile phases (Table 3). Consequently, F-1 and F-2 were decided as the new compounds. F-3 was closely related to a major component of Eurocidin- $T$, and cannot be distinguished from that of Eurocidin- $T$ chromatographically, which will be clarified by structure elucidation of these compounds. These three compounds belonged to eurocidin family, therefore F-1 and F-2 were named eurocidins C, D, respectively. F-3 was named eurocidin E tentatively, until the identification is performed among F-3 and purified eurocidin A or B from Eurocidin-T.

We isolated eurocidins $\mathrm{C}, \mathrm{D}$ and $\mathrm{E}$ by the inhibitory action of mast cell degranulation induced by compound 48/80, while Eurocidin-T was screened as an antifungal antibiotic. Analogy of physico-chemical properties among eurocidins $\mathrm{C}, \mathrm{D}, \mathrm{E}$ and Eurocidin-T suggests that these compounds possess similar biological activities. Indeed, Eurocidin- $T$ was found to have an inhibitory activity for rat mast cell degranulation. In our screening work for microorganisms, S. albireticuli IFO 12737 was found to possess an inhibitory activity against mast cell degranulation, which was estimated eurocidin related compounds (data not shown).

Further details on the structure elucidation of eurocidins $\mathrm{D}$ and $\mathrm{E}$ and biological activities of these compounds will be described in the succeeding papers ${ }^{9,10)}$. 
Table 3. HPLC retention times of eurocidins C, D and E and Eurocidin-T.

\begin{tabular}{|c|c|c|c|c|c|c|c|}
\hline \multirow{3}{*}{ Expt } & \multirow{3}{*}{ Column } & \multirow{3}{*}{ Mobile phase } & \multicolumn{5}{|c|}{ Retention time (minutes) } \\
\hline & & & \multicolumn{3}{|c|}{ Eurocidin } & \multicolumn{2}{|c|}{ Eurocidin-T } \\
\hline & & & $\mathrm{C}(\mathrm{F}-1)$ & $D(F-2)$ & $E(F-3)$ & 1st peak & 2nd peak \\
\hline 1 & $\begin{array}{c}\mathrm{C}_{8} \\
\text { (analytical) }\end{array}$ & $\begin{array}{c}\mathrm{CH}_{3} \mathrm{CN}-\mathrm{AcONH}_{4}(\mathrm{pH} 5.0) \\
33: 67\end{array}$ & 4.8 & 7.6 & 11.0 & 6.7 & 11.0 \\
\hline 2 & $\begin{array}{c}\mathrm{C}_{8} \\
\text { (analytical) }\end{array}$ & $\begin{array}{c}\mathrm{CH}_{3} \mathrm{CN}-\mathrm{NaH}_{2} \mathrm{PO}_{4}(\mathrm{pH} 2.9) \\
35: 65\end{array}$ & 8.6 & 14.3 & 23.4 & 13.6 & 23.4 \\
\hline 3 & $\begin{array}{c}\mathrm{C}_{8} \\
\text { (analytical) }\end{array}$ & $\begin{array}{l}\mathrm{MeOH}-\mathrm{AcONH}_{4} \text { (pH 5.0) } \\
\quad 63: 37\end{array}$ & 6.4 & 9.8 & 12.5 & 8.3 & 12.8 \\
\hline 4 & $\begin{array}{c}\mathrm{C}_{8} \\
\text { (preparative) }\end{array}$ & $\begin{array}{c}\mathrm{CH}_{3} \mathrm{CN}-\mathrm{AcONH}_{4}(\mathrm{pH} 5.0) \\
31: 69\end{array}$ & 3.0 & 21.3 & 31.0 & 19.0 & 31.0 \\
\hline 5 & $\mathrm{C}_{18}$ & $\begin{array}{c}\mathrm{CH}_{3} \mathrm{CN}-\mathrm{AcONH}_{4}(\mathrm{pH} 5.0) \\
35: 65\end{array}$ & 5.4 & 9.4 & 14.3 & 7.7 & 14.2 \\
\hline 6 & $\mathrm{C}_{2}$ & $\begin{array}{c}\mathrm{CH}_{3} \mathrm{CN}-\mathrm{AcONH}_{4}(\mathrm{pH} 5.0) \\
25: 75\end{array}$ & 6.2 & 9.7 & 13.1 & 8.2 & 13.1 \\
\hline
\end{tabular}

Column: Expt 1 3, Lichrosorb RP-8 (5 $\mu \mathrm{m}, 125 \times 4 \mathrm{~mm}$ i.d. $)$; Expt 4, Nucleosil $5 \mathrm{C}_{\mathbf{8}}(5 \mu \mathrm{m}, 250 \times 10 \mathrm{~mm}$ i.d. $)$; Expt 5, YMC A-302 (5 $\mathrm{m}, 150 \times 4.6 \mathrm{~mm}$ i.d.); and Expt 6, TMS-250 (75 $\times 4.6 \mathrm{~mm}$ i.d.). Mobile phase: Expt 1, $4 \sim 6$, acetonitrile - $10 \mathrm{~mm} \mathrm{AcOH}-\mathrm{AcONH}_{4}$ buffer ( $\mathrm{pH}$ 5.0); Expt 2, acetonitrile - $10 \mathrm{mM} \mathrm{H}_{3} \mathrm{PO}_{4}-\mathrm{NaH}_{2} \mathrm{PO}_{4}$ buffer ( $\mathrm{pH} 2.9$ ); and Expt 3, MeOH-10 mM AcOH-AcONH 4 buffer (pH 5.0). Flow rate: Expt 1 3, 5, $1 \mathrm{ml} / \mathrm{minute}$; Expt 4, $4 \mathrm{ml} / \mathrm{minute}$; and Expt $6,0.8 \mathrm{ml} / \mathrm{minute}$. Detector: UV $350 \mathrm{~nm}$.

\section{Acknowledgments}

The authors are indebted to Professor Hideo Suzuki of Tokyo Agricultural College for his valuable comments and suggestions.

\section{References}

1) Wasserman, S. I.: The mast cell and the inflammatory response. In The Mast Cell; Its Role in Health and Disease. Eds., J. Pepys \& A. M. Edwards, pp. 9 20, Pitman Medical Publishing Co., 1979

2) KAY, A. B.: Inflammatory cells in allergic disease. In Mast Cells; Mediators and Disease. Ed., S. T. HolGATE, pp. $227 \sim 239$, Kluwer Academic Publishers, 1988

3) Yamasaki, H.; K. TaSaKa, K. SAeKi \& S. IRINO: Histamine release inhibition in anti-inflammatory mechanism. Acta Med. Okayama 24: $113 \sim 129,1970$

4) Hirai, Y.; H. Takase, H. Kobayashi, M. Yamamoto, N. Fuhoka, H. Kohda, K. Yamasaku, T. Yasuhara \& T. NAKAJIMA: Screening test for anti-inflammatory crude drugs based on inhibition effect of histamine release from mast cell. Shoyakugaku Zasshi (Japanese) 37: 374 380, 1983

5) Nakagomi, K.; H. Suzuki, N. Tomizuka, T. Yasuhara \& T. Nakajima: A method to screen microbes producing biologically active substances that react on isolated rat peritoneal mast cells. Rep. Ferm. Res. Inst. Jpn. 63: $13 \sim 21,1985$

6) SAEKI, K.: Effects of compound 48/80, chymotrypsin and antiserum on isolated mast cells under aerobic and anaerobic conditions. Jpn. J. Pharmacol. 14: 375 390, 1964

7) Nakazawa, K.: Studies on streptomycetes. Eurocidin, an antibiotic produced by Streptomyces albireticuli (III). J. Agric. Chem. Soc. Jpn. 29: 650 652, 1955

8) Horil, S.; T. Shima \& A. Ouchida: Partial structure of the eurocidin complex. J. Antibiotics 23: 102 104, 1970

9) Nakagomi, K.; S. Sakai, H. Tanaka, N. Tomizuka, Y. Kawakami \& T. Nakamma: Studies on inhibitors of rat mast cell degranulation produced by microorganisms. II. Structure elucidation of eurocidins D and E. J. Antibiotics 43: $470 \sim 476,1990$

10) Nakagomi, K.; K. Masuda, H. Tanaka, N. Tomizuka, Y. Mitsui \& T. Nakajima: Studies on inhibitors of rat mast cell degranulation produced microorganisms. HI. Biological and anti-microbial activities of eurocidins $\mathrm{C}$, D and E. J. Antibiotics, in preparation 